\title{
Do Industries Lead Fama-French Factor Returns in Japan?
}

\author{
Chikashi Tsuji
}

Graduate School of Systems and Information Engineering, University of Tsukuba, Japan

\begin{abstract}
We investigate whether the returns of industry portfolios in Japan predict Fama and French's well-known smallminus-big (SMB) and high-minus-low (HML) factor returns. In Japan, a significant number of industry returns, such as from glass and ceramics products, iron and steel, machinery, textiles and apparel, and marine transportation, forecast either SMB or HML factor returns by up to two or three months. These results hold even after controlling for many predictable macroeconomic variables. These findings suggest that industry returns contain profitable information on Fama-French SMB and HML factor returns, and this provides useful practical information for equity investment businesses.
\end{abstract}

\section{INTRODUCTION}

Are industry returns useful for equity investment? Is the information currently contained in industry returns used as much as it merits to understand real equity markets? Recent influential research by Hong et al. [1] found that industry returns lead the US stock market. Hong et al. [1] concluded that these findings support the gradual-information-diffusion hypothesis. This suggests that markets incorporate the information about their fundamentals in industry returns with a lag, because information diffuses gradually across asset markets. In turn, the hypothesis of Hong et al. [1] is derived from suggestions in the recent behavioral finance literature, including Shiller [2] and Sims [3], that investors are rationally bounded and have limited information-processing capacity. With this in mind, Hong et al. [1] focused on excess market and industry returns. ${ }^{2}$

In contrast, substantive work by Fama and French (including Fama and French [32-37]) demonstrated that not only excess market returns but also small-minus-big (SMB) and high-minus-low (HML) factor returns play a significant role in stock markets. Thus, although the gradualinformation-diffusion hypothesis may not be directly applied, it is meaningful to investigate whether the returns of industry portfolios predict SMB and HML factor returns. ${ }^{3}$

*Address correspondence to this author at the Graduate School of Systems and Information Engineering, University of Tsukuba, Japan;

E-mail:mail_sec_low@minos.ocn.ne.jp

\footnotetext{
${ }^{1}$ Other studies broadly relating to this viewpoint include Kahneman [4], Nisbett and Ross [5], Merton [6], Hong and Stein [7], Brennan [8], Allen and Gale [9], Peng and Xiong [10], Hirshleifer et al. [11], Blume and Friend [12], King and Leape [13], Chan [14], Chakrabarti [15], Grinblatt and Keloharju [16], Peng and Xiong [17], Coval and Thakor [18], Ko and Huang [19], Povel et al. [20], Basak et al. [21], Booth et al. [22], Barber and Odean [23], and Acharya and Yorulmazer [24].

${ }^{2}$ Other studies investigating industry returns include Lo and MacKinlay [25], Brennan et al. [26], Badrinath et al. [27], Jegadeesh and Titman [28], Boudoukh et al. [29], Eleswarapu and Tiwari [30], and Pollet [31].

${ }^{3}$ In the US, SMB and HML factor returns are as popular as market returns, which are used in Hong et al. [1]. Hence if we assume that the information levels included in the three factors are the same in the US, then if industry returns lead SMB and HML returns, it could be interpreted as evidence that supports the gradual-information-diffusion hypothesis in the US. However, in Japan, SMB and HML returns are currently not as popular as market returns, and so the situation may be a little different from that in the US.
}

This will help deepen our knowledge of stock return relations in Japan. Hence our objective is to test the predictability of industry portfolios for SMB and HML factor returns using the Japanese stock market and macroeconomic data. As far as the authors are aware, there is no existing research on the relation between industry returns and Fama-French factors in Japan. We suggest that one reason for the limited extant research is that researchers are obliged to construct these factors by themselves from the beginning.

Our contribution is as follows. First, we find that in Japan a significant number of industry returns forecast SMB returns by up to two months. Second, a significant number of industry returns also forecast HML returns by up to three months. These forecasting abilities are found even after controlling for many predictable macroeconomic variables. Third, we show that in Japan HML returns lag a little behind SMB returns. This result is obtained using mutual impulse response analysis of the SMB and HML series.

The rest of this paper is organized as follows. Section II explains the data used. In Section III we describe the test methodology and empirical results. Section IV concludes the paper.

\section{DATA}

The sample period of the data set used in the paper is from October 1981 to December 2004. We first construct the Fama-French SMB and HML for Japan. ${ }^{4}$ We also use 28 industry returns obtained from the Japan Securities Research Institute. The following abbreviations denote the industries. AGRIC: Fishing, Agriculture \& Forestry; MINES: Mining; CNSTR: Construction; FOOD: Foods; TXTLS: Textiles \&

\footnotetext{
${ }^{4}$ Using Tokyo Stock Exchange (TSE) First Section stocks and following Fama and French [33], we construct the SMB and HML factor returns. SMB is the monthly difference between the average of the returns on the three small-stock portfolios (small/low, small/middle, and small/high) and the average of the returns on the three big-stock portfolios (big/low, big/middle, and big/high), while HML is the difference between the average of the returns on the two high-BE/ME portfolios (small/high and big/high) and the average of the returns on the two low-BE/ME portfolios (small/low and big/low). Small-stock portfolios and big-stock portfolios are constructed by allocating the TSE First Section stocks by their size, and high-BE/ME and low-BE/ME portfolios are constructed by allocating the TSE First Section stocks by their BE/ME ratios. We strictly follow the methodology of Fama and French [33].
} 
Apparel; PAPER: Pulp \& Paper; CHEMS: Chemicals; OIL: Oil \& Coal Products; RUBBR: Rubber Products; GLASS: Glass \& Ceramics Products; STEEL: Iron \& Steel; NMETA: Nonferrous Metals; METAL: Metal Products; MACHN: Machinery; ELCTR: Electric Appliances; TRANS: Transportation Equipment; INSTR: Precision Instruments; OPRO: Other Products; COMCE: Commerce; MONEY: Banks, Securities, Insurance \& Other Financial Business; RLEST: Real Estate; LAND: Land Transportation; MARINE: Marine Transportation; AIR: Air Transportation; WHSE: Warehousing \& Harbor Transportation Services; INFO: Information \& Communication; GAS: Electric Power \& Gas; SRVC: Services.

Other variables used for prediction are INF, DSPR, MDY and MVOL, following Hong et al. [1]; these denote the following. INF is the inflation rate of the Consumer Price Index (CPI) (from the Statistics Bureau, Ministry of Internal Affairs and Communications); DSPR is the default spread between the yields of the long-term Nikkei Bond Index (from Nikkei, Inc.) and 10-year government bonds (from the Bank of Japan); MDY is the dividend yield of the Tokyo Stock Exchange's (TSE) first section; and MVOL is the historical one-year market volatility of the TSE first section stock returns (the return data is also from the Japan Securities Research Institute).

\section{PREDICTIVE REGRESSIONS INVOLVING IN- DUSTRY AND FAMA-FRENCH FACTORS}

Here we explore the ability of industry returns to lead SMB and HML returns in Japan. To see whether industries can forecast Fama and French's SMB and HML in Japan, we estimate the following specification separately for each of the 28 portfolios:

$$
\begin{aligned}
& S M B_{t}=\alpha_{i}+\lambda_{i} R_{i, t-1}+\boldsymbol{A}_{\boldsymbol{i}} \boldsymbol{Z}_{\boldsymbol{t}-\mathbf{1}}+\eta_{i, t}, \\
& H M L_{t}=\alpha_{i}+\lambda_{i} R_{i, t-1}+\boldsymbol{A}_{\boldsymbol{i}} \boldsymbol{Z}_{\boldsymbol{t}-\mathbf{1}}+\eta_{i, t},
\end{aligned}
$$

where $R_{i, t-1}$ is the return of industry portfolio $i$ lagged one month, $\boldsymbol{Z}_{t-1}$ is a vector of additional market predictors. We include a number of well-known market predictors in $\boldsymbol{Z}_{t-1}$ as a set of control variables. Among these is the INF (Fama and Schwert [38]), the DSPR (Fama and French [39]), MDY (Campbell and Shiller [40]) and MVOL (Hong et al. [1]). These variables are generally thought to proxy for time varying risk in the established financial literature. We also include $\mathrm{SMB}_{t-1}$ in $\boldsymbol{Z}_{\boldsymbol{t}-\mathbf{1}}$ of equation (1), and HML ${ }_{t-1}$ in $\boldsymbol{Z}_{\boldsymbol{t}-\mathbf{1}}$ of equation (2).

Tables 1 and $\mathbf{2}$ summarize the empirical results. In Tables 1 and 2, we display the results of (1) each 28 regression and (2) the joint test of the null hypothesis that all the $\lambda_{i} \mathrm{~s}$ equal zero $\left(\lambda_{1}=\lambda_{2}=\ldots=\lambda_{28}=0\right)$ for each of the three dependent variables (month $t$, month $t+1$, and month $t+2 \mathrm{SMB}$ and HML factor returns). For the joint test, we stack the regressions given by (1) or (2) into a single system and perform Wald tests of the joint significance of the coefficients. Values of the Wald test statistic and corresponding $p$-values are reported in the final rows of Tables $\mathbf{1}$ and $\mathbf{2}$. First, as shown in Table 1, for month $t$ returns, seven out of 28 industries lead the SMB factor returns; for month $t+1$, eight industries lead the SMB factor returns; and for month $t+2$, no industry leads SMB factor returns. Moreover, as shown in Table 2, for month $t$ returns, 12 out of 28 industries lead HML factor returns; for month $t+1$, eight industries lead HML factor returns; and likewise for month $t+2$, eight industries lead the HML factor returns.

As shown by the Wald test results for the SMB factors in Table 1, for month $t$ returns we can reject the null hypothesis that all the $\lambda_{i} \mathrm{~s}$ equal zero at the $1 \%$ level of significance. For the month $t+1$ SMB factor returns, we can reject the null at the $5 \%$ level of significance. For the month $t+2$ returns, we fail to reject the null. In terms of the Wald tests for the HML factors, as shown in Table 2, we can reject the null hypothesis that all the $\lambda_{i}$ s equal zero at the $1 \%$ level of significance for the month $t$ and $t+1$ returns. For the month $t+2$ HML factor returns, we reject the null at the $5 \%$ level of significance. Thus, in Japan industries generally predict HML better than SMB. ${ }^{5}$

To understand better the difference in the results for SMB and HML, we estimate a Vector Autoregressive (VAR) model with three lags, ${ }^{6}$ and depict the impulse responses between SMB and HML in Figs. (1) and (2). As shown in Fig. (1), when there is a shock of one standard deviation to the HML innovation, SMB has already positively responded. For the HML, after there is a shock of one standard deviation to the SMB innovation, HML gradually positively responds. From this phenomenon, we can see that HML returns lag a little behind SMB returns in Japan, and this brings about the difference in results in Tables $\mathbf{1}$ and $\mathbf{2}$. We also propose that SMB is more sensitive than HML to Japanese business cycles, and consequently, industries cannot forecast SMB better than HML.

Furthermore, as far as the authors are aware, this is the first research that examines whether industries lead the Fama-French SMB and HML factors in Japan, and evidence on this for other countries does not yet exist. Hence if the same tests are implemented in other markets, different results might be obtained because of differences in the popularity of SMB and HML returns, differences in market structure, and so on. Thus tests similar to ours in other international markets are interesting for both practical business investment decisions and the academic field of finance.

\section{CONCLUSIONS}

This paper investigates whether industry returns in Japan lead Fama-French factor returns. We find that in Japan the returns of industry portfolios are able to predict the movements of Fama and French's SMB and HML factor returns. These results are similar to the finding by Hong et al. [1] that industry returns lead US excess market returns.

\footnotetext{
${ }^{5}$ Furthermore, in our Tables $\mathbf{1}$ and $\mathbf{2}$, the adjusted $R$-squared values are generally low; however, these results are very similar to those of Hong et al. [1]. Our models (1) and (2) follow their model (3), and in Table 3 in Hong et al. [1], the average $R$-squared values are 0.041 (the one-month-ahead forecast), 0.019 (the two-months-ahead forecast), and 0.017 (the three-monthsahead forecast), respectively. More importantly, our focus in this paper is not on the construction of an effective forecasting model but on clarifying whether industry returns lead SMB and HML returns. Namely, low $R-$ squared values are not as important in our tests as they are in Hong et al. [1], and the significance of the coefficients of models (1) and (2) is much more important in our tests.

${ }^{6}$ We decided the length of lags used in the VAR as three, because the lag order was consistent with the analysis in Tables $\mathbf{1}$ and $\mathbf{2}$, where the relation between the first lag of industry returns and the month $t, t+1$, and $t+2 \mathrm{SMB}$ and HML was tested.
} 
Table 1. Predictive Regressions Involving Various Industry and SMB Factor Returns

\begin{tabular}{|c|c|c|c|c|c|c|}
\hline \multirow{3}{*}{ Industry } & \multicolumn{6}{|c|}{ Forecast of SMB Using Industry Returns at Various Horizons (H) } \\
\hline & \multicolumn{2}{|c|}{ Month $t$} & \multicolumn{2}{|c|}{ Month $t+1$} & \multicolumn{2}{|c|}{ Month $t+2$} \\
\hline & IND(-1) & Adj. $R^{2}$ & IND(-1) & Adj. $R^{2}$ & IND(-1) & Adj. $R^{2}$ \\
\hline "AGRIC & "0.0111 & 0.0000 & 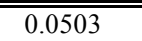 & 0.0124 & -0.0042 & 0.0067 \\
\hline$p$-value & 0.8656 & & 0.3064 & & 0.9153 & \\
\hline MINES & 0.0397 & 0.0045 & 0.0042 & 0.0078 & 0.0113 & 0.0071 \\
\hline$p$-value & 0.2967 & & 0.8853 & & 0.7097 & \\
\hline CNSTR & 0.0027 & -0.0003 & 0.0314 & 0.0100 & -0.0244 & 0.0081 \\
\hline$p$-value & 0.9531 & & 0.4307 & & 0.4317 & \\
\hline FOOD & 0.0875 & 0.0092 & 0.0569 & 0.0117 & -0.0357 & 0.0083 \\
\hline$p$-value & 0.1716 & & 0.2461 & & 0.4875 & \\
\hline TXTLS & 0.0409 & 0.0025 & 0.0770 * & 0.0174 & -0.0080 & 0.0068 \\
\hline$p$-value & 0.4449 & & 0.0722 & & 0.8316 & \\
\hline PAPER & 0.0043 & -0.0002 & 0.0634 & 0.0158 & -0.0347 & 0.0091 \\
\hline$p$-value & 0.9346 & & 0.1789 & & 0.3690 & \\
\hline CHEMS & 0.0733 & 0.0073 & 0.0283 & 0.0088 & -0.0402 & 0.0089 \\
\hline$p$-value & 0.1853 & & 0.5245 & & 0.3410 & \\
\hline OIL & 0.0389 & 0.0037 & 0.0293 & 0.0099 & -0.0142 & 0.0072 \\
\hline$p$-value & 0.3459 & & 0.3840 & & 0.6254 & 0.0072 \\
\hline RUBBR & 0.0580 & 0.0081 & 0.0437 & 0.0125 & -0.0243 & 0.0081 \\
\hline$p$-value & 0.1901 & & 0.2204 & & 0.4610 & \\
\hline GLASS & 0.0503 & 0.0048 & $0.0709 * *$ & 0.0177 & -0.0032 & 0.0067 \\
\hline$p$-value & 0.2669 & & 0.0381 & & 0.9274 & \\
\hline STEEL & -0.0201 & 0.0009 & $0.0702 * *$ & 0.0225 & -0.0050 & 0.0068 \\
\hline$p$-value & 0.6743 & & 0.0437 & & 0.8664 & \\
\hline NMETA & $0.0555^{*}$ & 0.0083 & 0.0438 & 0.0130 & 0.0128 & 0.0071 \\
\hline$p$-value & 0.0705 & & 0.2108 & & 0.6346 & \\
\hline METAL & $0.1324 * *$ & 0.0281 & 0.0527 & 0.0122 & -0.0099 & 0.0068 \\
\hline$p$-value & 0.0134 & & 0.2274 & & 0.8322 & \\
\hline MACHN & $0.0707 *$ & 0.0083 & $0.0873 * *$ & 0.0208 & -0.0086 & 0.0068 \\
\hline$p$-value & 0.0857 & & 0.0166 & & 0.8159 & \\
\hline ELCTR & $0.0980 * *$ & 0.0249 & 0.0385 & 0.0116 & -0.0095 & 0.0069 \\
\hline$p$-value & 0.0139 & & 0.3455 & & 0.7692 & \\
\hline TRANS & $0.1285^{* *}$ & 0.0293 & $0.0940 * *$ & 0.0235 & -0.0236 & 0.0077 \\
\hline$p$-value & 0.0077 & & 0.0086 & & 0.6014 & \\
\hline INSTR & $0.0993 * *$ & 0.0221 & $0.0632 *$ & 0.0168 & -0.0164 & 0.0073 \\
\hline$p$-value & 0.0149 & & 0.0799 & & 0.6210 & \\
\hline OPRO & $0.1090 * *$ & 0.0170 & $0.0769 *$ & 0.0163 & -0.0499 & 0.0103 \\
\hline$p$-value & 0.0186 & & 0.0828 & & 0.2475 & \\
\hline COMCE & 0.0356 & 0.0021 & 0.0105 & 0.0079 & -0.0580 & 0.0129 \\
\hline$p$-value & 0.5859 & & 0.7764 & & 0.1182 & \\
\hline MONEY & -0.0001 & -0.0003 & 0.0238 & 0.0093 & -0.0482 & 0.0132 \\
\hline$p$-value & 0.9981 & & 0.4821 & & 0.2419 & \\
\hline RLEST & 0.0034 & -0.0002 & 0.0515 & 0.0175 & -0.0143 & 0.0074 \\
\hline$p$-value & 0.9122 & & 0.1563 & & 0.6307 & \\
\hline LAND & -0.0343 & 0.0022 & 0.0722 & 0.0186 & -0.0133 & 0.0071 \\
\hline$p$-value & 0.5622 & & 0.1660 & & 0.6642 & \\
\hline MARINE & -0.0103 & 0.0001 & $0.0552 *$ & 0.0192 & 0.0190 & 0.0080 \\
\hline$p$-value & 0.7700 & & 0.0680 & & 0.5543 & \\
\hline AIR & 0.0475 & 0.0066 & 0.0282 & 0.0101 & -0.0184 & 0.0077 \\
\hline$p$-value & 0.2205 & & 0.5380 & & 0.5924 & \\
\hline WHSE & 0.0137 & 0.0002 & 0.0330 & 0.0103 & -0.0113 & 0.0070 \\
\hline$p$-value & 0.7745 & & 0.4645 & & 0.7394 & \\
\hline INFO & -0.0051 & -0.0002 & -0.0089 & 0.0080 & -0.0238 & 0.0086 \\
\hline$p$-value & 0.9039 & & 0.8389 & & 0.3464 & \\
\hline GAS & -0.0141 & 0.0002 & 0.0471 & 0.0127 & -0.0270 & 0.0083 \\
\hline$p$-value & 0.8080 & & 0.5070 & & 0.4321 & \\
\hline SRVC & 0.0261 & 0.0010 & -0.0199 & 0.0084 & -0.0319 & 0.0086 \\
\hline$p$-value & 0.5964 & & 0.7318 & & 0.4419 & \\
\hline Wald test & $54.5133^{* *}$ & & $45.8999^{*}$ & & 10.4440 & \\
\hline$p$-value & 0.0019 & & 0.0178 & & 0.9990 & \\
\hline
\end{tabular}

Notes: This table presents forecasts of SMB factor returns using various industry portfolio returns (separately) at various horizons: month $t$, month $t+1$, month $t+2$. The other forecasting variables are lagged SMB (SMB factor return), INF (the CPI inflation rate), DSPR (the default spread between the yields of the long-term Nikkei Bond Index and 10-year government bonds), MDY (the dividend yield of the market portfolio), and market volatility (MVOL). We only report the coefficients before the lagged industry return. We used the Newey-West [41] method to correct the $t$-statistics used for evaluating the significance of the coefficients. We also report Wald tests of the joint significance of the coefficients estimated by constructing a system (joint test of the null hypothesis that all lambdas are zero). The statistics for the Wald tests ( 28 degrees of freedom) are displayed with their $p$ values at the bottom of the table. The sample period is October 1981 to December 2004 . *Significant at $10 \%$ level. **Significant at $5 \%$ level. 
Table 2. Predictive Regressions Involving Various Industry and HML Factor Returns

\begin{tabular}{|c|c|c|c|c|c|c|}
\hline \multirow{3}{*}{ Industry } & \multicolumn{6}{|c|}{ Forecast of HML Using Industry Returns at Various Horizons (H) } \\
\hline & \multicolumn{2}{|c|}{ Month $t$} & \multicolumn{2}{|c|}{ Month $t+1$} & \multicolumn{2}{|c|}{ Month $t+2$} \\
\hline & IND(-1) & Adj. $R^{2}$ & IND(-1) & Adj. $R^{2}$ & IND(-1) & Adj. $R^{2}$ \\
\hline "AGRIC & $0.0917 * *$ & 0.0476 & $0.0665 * *$ & 0.0192 & 0.0130 & -0.0121 \\
\hline$p$-value & 0.0015 & & 0.0173 & & 0.6028 & \\
\hline MINES & $0.0475 * *$ & 0.0256 & $0.0371 *$ & 0.0089 & 0.0327 & -0.0055 \\
\hline FOOD & $0.1000 * *$ & 0.0358 & $0.0653^{*}$ & 0.0104 & 0.0127 & -0.0124 \\
\hline$p$-value & 0.0110 & & 0.0830 & & 0.6608 & \\
\hline TXTLS & 0.0490 & 0.0187 & $0.0836 * *$ & 0.0242 & 0.0071 & -0.0126 \\
\hline$p$-value & 0.1146 & & 0.0139 & & 0.7750 & \\
\hline PAPER & 0.0383 & 0.0165 & 0.0191 & 0.0011 & 0.0076 & -0.0126 \\
\hline$p$-value & 0.2551 & & 0.4759 & & 0.7610 & \\
\hline CHEMS & 0.0305 & 0.0128 & $0.0677 *$ & 0.0121 & 0.0196 & -0.0118 \\
\hline$p$-value & 0.1193 & & 0.2289 & & 0.2410 & \\
\hline GLASS & 0.0485 & 0.0196 & 0.0326 & 0.0037 & $0.0784 * *$ & 0.0117 \\
\hline$p$-value & 0.1046 & & 0.2643 & & 0.0020 & \\
\hline STEEL & $0.0504 * *$ & 0.0255 & 0.0277 & 0.0041 & 0.0212 & -0.0101 \\
\hline$p$-value & 0.0286 & & 0.1853 & & 0.2677 & \\
\hline NMETA & $0.0522 *$ & 0.0247 & 0.0389 & 0.0076 & $0.0385 * *$ & -0.0049 \\
\hline$p$-value & 0.0533 & & 0.1004 & & 0.0392 & \\
\hline METAL & $0.1316^{* *}$ & 0.0788 & 0.0347 & 0.0043 & 0.0321 & -0.0087 \\
\hline$p$-value & 0.0001 & & 0.2602 & & 0.2719 & \\
\hline MACHN & $0.0695 * *$ & 0.0281 & 0.0298 & 0.0028 & $0.0484 * *$ & -0.0041 \\
\hline$p$-value & 0.0362 & & 0.3018 & & 0.0244 & \\
\hline ELCTR & -0.0011 & 0.0103 & -0.0164 & 0.0008 & $0.0490^{*}$ & -0.0013 \\
\hline$p$-value & 0.9714 & & 0.5626 & & 0.0675 & \\
\hline TRANS & $0.0784 * *$ & 0.0312 & 0.0265 & 0.0019 & $0.0684 * *$ & 0.0031 \\
\hline RLEST & 0.0191 & 0.0128 & $0.0424 *$ & 0.0123 & 0.0077 & -0.0124 \\
\hline$p$-value & 0.4525 & & 0.0874 & & 0.6695 & \\
\hline LAND & 0.0442 & 0.0181 & 0.0438 & 0.0072 & -0.0024 & -0.0128 \\
\hline$p$-value & 0.1653 & & 0.2064 & & 0.9148 & \\
\hline MARINE & $0.0441^{*}$ & 0.0255 & $0.0436 * *$ & 0.0144 & $0.0408 * *$ & 0.0002 \\
\hline$p$-value & 0.0541 & & 0.0160 & & 0.0333 & \\
\hline AIR & 0.0373 & 0.0188 & $0.0536^{*}$ & 0.0172 & 0.0086 & -0.0124 \\
\hline$p$-value & 0.2325 & & 0.0681 & & 0.7066 & \\
\hline WHSE & $0.0600 * *$ & 0.0286 & 0.0467 & 0.0106 & 0.0084 & -0.0125 \\
\hline$p$-value & 0.0329 & & 0.1067 & & 0.7204 & \\
\hline INFO & -0.0127 & 0.0112 & -0.0034 & -0.0004 & 0.0082 & -0.0124 \\
\hline$p$-value & 0.7332 & & 0.8878 & & 0.6970 & \\
\hline GAS & 0.0216 & 0.0123 & 0.0272 & 0.0027 & 0.0138 & -0.0120 \\
\hline$p$-value & 0.5603 & & 0.3897 & & 0.5644 & \\
\hline SRVC & 0.0293 & 0.0133 & -0.0102 & -0.0001 & 0.0150 & -0.0120 \\
\hline$p$-value & 0.4650 & & 0.7922 & & 0.6607 & \\
\hline Wald test & $101.8795^{* *}$ & & $53.5635^{* *}$ & & $43.6168^{*}$ & \\
\hline$p$-value & 0.0000 & & 0.0025 & & 0.0303 & \\
\hline
\end{tabular}




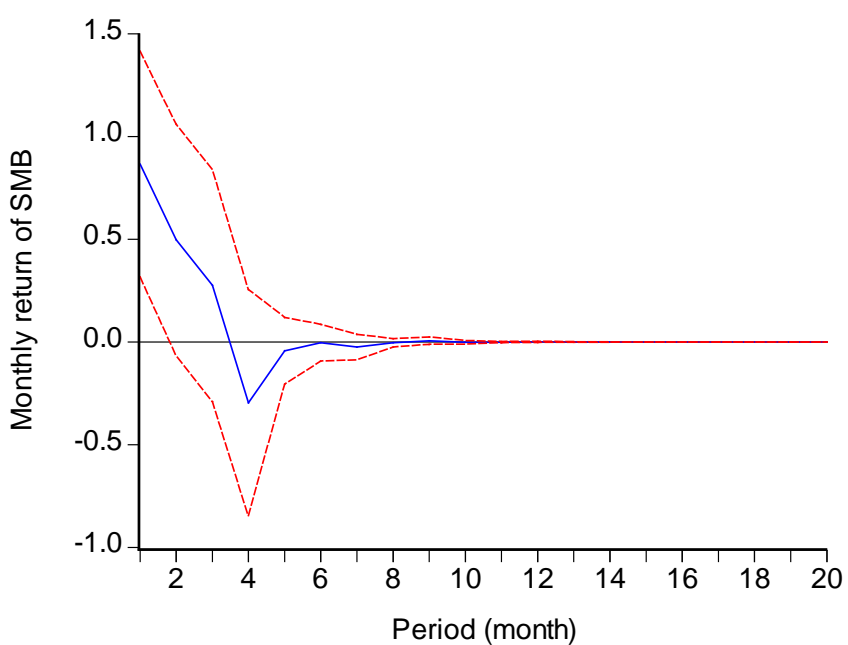

Fig. (1). Response of SMB to the one standard deviation shock to the HML innovation.

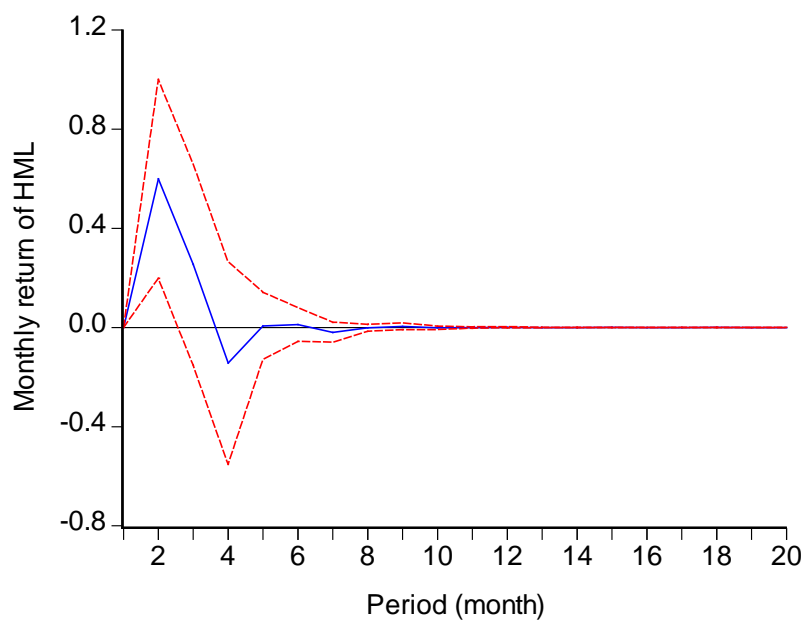

Fig. (2). Response of HML to the one standard deviation shock to the SMB innovation.

Hong et al. [1] urged that related empirical research be undertaken by following their analysis. This research adds to the evidence by supplying similar results using different materials, such as SMB and HML factor returns in Japan. As Fama and French demonstrated, SMB and HML factor returns play a significant role in equity markets in general. If these factor returns can be forecast from industry returns, studying the latter will lead to a useful and profitable strategy for equity investment. Our evidence also suggests that the information in industry returns could be more effectively used in Japan. Additional research in other international contexts should also be considered.

\section{ACKNOWLEDGEMENTS}

The authors acknowledge the generous financial assistance of the Japan Society for the Promotion of Science and the Zengin Foundation for Studies on Economics and Finance. We would also like to thank Jason McQueen for helpful discussions on several topics related to this paper and Takao Kobayashi for inviting us to seminars at Tokyo University, which were helpful in developing the ideas and important intuitions underlying the empirical analysis in this article. Furthermore, we are very grateful to two anonymous referees for their constructive and supportive comments on this paper. Finally, we greatly appreciate the invitation of Matthew Honan and Ambreen Lodhi to this new journal.

\section{REFERENCES}

[1] Hong H, Torous W, Valkanov R. Do industries lead stock markets? J Financ Econ 2007; 83: 367-96.

[2] Shiller R. Irrational Exuberance. New York: Broadway Books; 2000.

[3] Sims C. Rational Inattention. Working Paper Princeton University; 2001.

[4] Kahneman D. Attention and Effort. New Jersey: Prenctice-Hall; 1973.

[5] Nisbett R, Ross L. Human inference: strategies and shortcomings of social judgment 1980; Prentice-Hall: New Jersey.

[6] Merton R. A simple model of capital market equilibrium with incomplete information. J Finance 1987; 42: 483-510.

[7] Hong H, Stein J. A unified theory of underreaction, momentum trading and overreaction in asset markets. J Finance 1999; 54: 2143-84.

[8] Brennan M. The optimal number of securities in a risky asset portfolio when there are fixed costs of transacting: Theory and some empirical results. J Financ Quant Anal 1975; 10: 483-96.

[9] Allen F, Gale D. Limited market participation and volatility of asset prices. Am Econ Rev 1994; 84: 933-55.

[10] Peng L, Xiong W. Capacity constrained learning and asset price comovements. Working Paper 2002; Princeton University.

[11] Hirshleifer D, Lim S, Teoh SH. Disclosure to a credulous audience: the role of limited attention. Working Paper 2002; Ohio State University.

[12] Blume M, Friend I. The changing role of the individual investors: A Twentieth Century Fund Report. New York: Wiley; 1978.

[13] King M, Leape J. Wealth and portfolio composition: Theory and evidence. NBER Working Paper 1984; No.1468.

[14] Chan WS. Stock price reaction to news and no-news: drift and reversal after headlines. J Financ Econ 2000; 70: 223-60.

[15] Chakrabarti R. Just another day in the inter-bank foreign exchange market. J Financ Econ 2000; 56: 29-64.

[16] Grinblatt M, Keloharju M. The investment behavior and performance of various investor types: a study of Finland's unique data set. J Financ Econ 2000; 55: 43-67.

[17] Peng L, Xiong W. Investor attention, overconfidence and category learning. J Financ Econ 2006; 80: 563-602.

[18] Coval JD, Thakor AV. Financial intermediation as a beliefs-bridge between optimists and pessimists. J Financ Econ 2005; 75: 535-69.

[19] Ko KJ, Huang Z. Arrogance can be a virtue: Overconfidence, information acquisition, and market efficiency. J Financ Econ 2007; 84: 529-60.

[20] Povel P, Singh R, Winton A. Booms, busts, and fraud. Rev Financ Stud 2007; 20: 1219-54.

[21] Basak S, Pavlova A, Shapiro A. Optimal asset allocation and risk shifting in money management. Rev Financ Stud 2007; 20: 1583621.

[22] Booth GG, Lin J, Martikainen T, Tse Y. Trading and pricing in upstairs and downstairs stock markets. Rev Financ Stud 2002; 15: 1111-35.

[23] Barber BM, Odean T. All that glitters: the effect of attention and news on the buying behavior of individual and institutional investors. Rev Financ Stud 2008 (in press).

[24] Acharya VV, Yorulmazer T. Cash-in-the-market pricing and optimal resolution of bank failures. Rev Financ Stud 2008 (in press).

[25] Lo A, MacKinlay C. When are contrarian profits due to stock market overreaction? Rev Financ Stud 1990; 3: 175-206.

[26] Brennan M, Jegadeesh N, Swaminathan B. Investment analysis and the adjustment of stock prices to common information. Rev Financ Stud 1993; 6: 799-824.

[27] Badrinath S, Kale J, Noe T. Of shepherds, sheep and the crossautocorrelations in equity returns. Rev Financ Stud 1995; 8: 40130 .

[28] Jegadeesh N, Titman S. Overreaction, delayed reaction and contrarian profits. Rev Financ Stud 1995; 8: 973-93.

[29] Boudoukh J, Richardson M, Whitelaw R. A tale of three schools: Insights on autocorrelations of shorthorizon stock returns. Rev Financ Stud 1994; 7: 539-73. 
[30] Eleswarapu V, Tiwari A. Business cycles and stock market returns: Evidence using industry-based portfolios. J Financ Res 1996; 19: 121-34.

[31] Pollet J. Predicting asset returns with expected oil price changes. Working Paper 2002; Harvard University.

[32] Fama E, French K. The cross-section of expected stock returns. J Finance 1992; 47: 427-65.

[33] Fama E, French K. Common risk factors in the returns on stocks and bonds. J Financ Econ 1993; 33: 3-56.

[34] Fama E, French K. Size and book-to-market factors in earnings and returns. J Finance 1995; 50: 131-55.

[35] Fama E, French K. Multifactor explanations of asset pricing anomalies. J Finance 1996; 51: 55-84.
[36] Fama E, French K. Industry costs of equity. J Financ Econ 1997; 43: 153-93.

[37] Fama E, French K. The value premium and the CAPM. J Finance 2006; 61: 2137-62.

[38] Fama E, Schwert GW. Asset returns and inflation. J Financ Econ 1977; 5: 115-46.

[39] Fama E, French K. Business conditions and expected returns on stocks and bonds. J Financ Econ 1989; 25: 23-49.

[40] Campbell J, Shiller R. The dividend-price ratio and expectations of future dividends and discount factors. Rev Financ Stud 1988; 1: 195-228.

[41] Newey W, West K. A simple positive semi-definite, heteroskedasticity and autocorrelation consistent covariance matrix. Econometrica $1987 ; 55: 703-8$.

(C) Chikashi Tsuji; Licensee Bentham Open.

This is an open access article distributed under the terms of the Creative Commons Attribution License (http://creativecommons.org/licenses/by/2.5/), which permits unrestrictive use, distribution, and reproduction in any medium, provided the original work is properly cited. 